\title{
Profil Tingkat Kebugaran Jasmani Antara Siswa yang Bersekolah di Kota (SMPN 1 Purwakarta) dan di Desa (SMPN 2 Cibatu) di Kabupaten Purwakarta
}

\author{
Ari Gana Yulianto1, Aris Risyanto², Deni Mudian³ ${ }^{3}$ Iyan Nurdian Haris ${ }^{4}$ \\ Program Studi Pendidikan Jasmani Kesehatan dan Rekreasi, Fakultas Keguruan dan Ilmu \\ Pendidikan, Universitas Subang ${ }^{1,2,3}$ \\ Program Studi Pendidikan Jasmani Kesehatan dan Kesehatan, Fakultas Keguruan dan Ilmu \\ Pendidikan, Universitas Sepuluh November ${ }^{4}$ \\ arigana05@gmail.com¹, arisrisyanto@unsub.ac.id², mudiandeni@gmail.com³ \\ iyanhariss@usn.ac.id ${ }^{4}$
}

\begin{abstract}
Abstrak
Tingkat kebugaran siswa yang sebenarnya sangat berpengaruh pada kehidupan sehari-hari. Wilayah geologi mempengaruhi Tingkat Kebugaran Jasmani siswa. Pemeriksaan ini bertujuan untuk mengetahui perbedaan tingkat kebugaran antara siswa yang ada di kota (SMPN 1 Purwakarta) dan siswa yang ada di desa (SMPN 2 Cibatu). Pemeriksaan ini merupakan penelitian kuantitatif dengan menggunakan teknik tinjauan atau survey. Jenis tinjauan yang digunakan adalah tinjauan cross sectional dengan berbagai informasi menggunakan tes dan pengukuran. Populasi dalam ujian ini adalah sekolah menengah pertama yang menggambarkan sekolah dari kota dan sekolah menengah pertama yang menggambarkan sekolah dari desa di Kabupaten Purwakarta, yang berjumlahkan 80 sekolah sehingga metode pemeriksaan yang digunakan adalah pengujian purposive, contoh pada Penelitian ini adalah siswa kelas VIII SMPN 1 Purwakarta (60 siswa) dan siswa kelas VIII SMPN 2 Cibatu (60 siswa). Ragam informasi yang digunakan tes dengan instrumen Tes Kesegaran Jasmani Indonesia (TKJI) berumur 13-15 tahun. dari Kementerian Pendidikan Nasional. Metode pemeriksaan menggunakan investigasi dan persentase. Pemeriksaan informasi menunjukkan bahwa terdapat perbedaan tingkat kebugaran antara siswa yang belajar di kota (SMPN 1 Purwakarta) dan siswa yang belajar di desa (SMPN 2 Cibatu), siswa yang bersekolah di desa (SMPN 2 Cibatu) memiliki derajat kebugaran Memang lebih baik dari siswa yang konsentrasi di kota (SMP 1 Purwakarta) dengan nilai normal SMPN 1 Purwakarta sebesar 12,83 dan SMPN 2 Cibatu sebesar 15,40.
\end{abstract}

Kata Kunci: Kebugaran fisik; Siswa; SMPN 1 Purwakarta; SMPN 2 Cibatu; Wilayah Geologi.

Abstract

The actual level of student fitness is very influential in everyday life. Geological area affects the Physical Fitness Level of students. This examination aims to determine the difference in fitness levels between students in the city (SMPN 1 Purwakarta) and students in the village (SMPN 2 Cibatu). This examination is a quantitative study using a review or survey technique. The type of review used is a cross sectional review with various information using tests and measurements. The population in this exam is a junior high school that describes a school from a city and a junior high school that describes a school from a village in Purwakarta Regency, which totals 80 schools so that the examination method used is purposive testing, the example in this study is class VIII SMPN 1 Purwakarta (60 students) and class VIII students of SMPN 2 Cibatu (60 students). The variety of information used in the test using the Indonesian Physical Fitness Test (TKJI) instrument is 13-15 years old. from the Ministry of National Education. The examination method uses investigation and percentage. Examination of information shows that there is a difference in fitness levels between students studying in the city (SMPN 1 Purwakarta) and students studying in the village (SMPN 2 Cibatu), students who study in the village (SMPN 2 Cibatu) have a degree of fitness Indeed better than students who concentration in the city (SMP 1 Purwakarta) with a normal value of SMPN 1 Purwakarta of 12.83 and SMPN 2 Cibatu of 15.40. Keywords: Physical fitness; Students; SMPN 1 Purwakarta; SMPN 2 Cibatu; geological area. 


\section{PENDAHULUAN}

Sekolah adalah sebuah karya untuk membantu semangat siswa baik secara sungguh-sungguh maupun secara intelektual, dari masa remaja hingga dewasa yang lebih baik, sebagai gambaran yang dapat diungkapkan nasehat atau pelajaran bagi anak-anak agar bisa berlari lebih baik, tidak merepotkan orang lain yang sedang bekerja, mengetahui seperti apa kerapian, memakai pakaian, tentang orang yang lebih mapan dan menyayangi yang lebih muda, benar-benar fokus satu sama lain, itulah salah satu ilustrasi interaksi instruktif untuk memperbaiki manusia (syafitri, 2020).

Sekolah yang dikoordinasikan oleh otoritas publik adalah sekolah yang didanai pemerintah. Sekolah-sekolah yang didanai pemerintah dikoordinasikan untuk memberikan pelatihan sesuai dengan motivasi di balik pengajaran yang baik secara umum, Ada juga sekolah non-pemerintah untuk menjadi sekolah berbasis pendidikan khusus, sekolah non-publik dikoordinasikan untuk mengatasi masalah unik yang tidak dapat diberikan oleh sekolah yang didanai negara misalnya pelatihan ketat dari atas ke bawah atau instruksi olahraga yang mengulas olahraga semua lebih mendalam.

Dalam rencana pendidikan instruktif terdapat beberapa mata pelajaran yang diajarkan, salah satunya adalah pendidikan jasmani. Siregar, n.d. (2020), menyatakan bahwa "actual instruction is a period of the keseluruhan instruktif cycle yang diidentikkan dengan gerakan, reaksi otot yang dinamis dan diidentifikasikan dengan progresi yang dihasilkan orang dari reaksi tersebut". Sementara itu, seperti yang ditunjukkan oleh anshor, (2016), menyatakan bahwa "pengajaran yang sebenarnya adalah periode program pembelajaran pada umumnya yang menambah pengalaman bergerak, untuk pengembangan dan peningkatan semua dalam semua untuk siswa.

Melihat gambaran di atas, cenderung beralasan bahwa "persekolahan yang sebenarnya adalah interaksi edukatif yang memanfaatkan kerja aktif melalui pengembangan, permainan, dan olahraga sebagai media untuk menumbuhkan kapasitas dan kemampuan siswa sehingga mereka dapat berkreasi secara menyeluruh, terutama mendorong pada 3 bagian pelatihan, menjadi spesifik intelektual, emosional, dan psikomotor". Salah satu tujuan utama dari sekolah yang sebenarnya adalah untuk membidik pada sudut psikomotor, untuk lebih spesifik bekerja pada kebugaran siswa yang sebenarnya. Karena kebugaran yang sebenarnya adalah bagian penting dari psikomotor, yang tergantung pada kemajuan kemampuan alami organ tubuh.

Kebugaran yang sebenarnya adalah tingkat kesejahteraan dinamis seseorang yang berubah menjadi kemampuan dasar untuk memiliki pilihan untuk melakukan tugas yang harus diselesaikan. Selanjutnya, penting untuk membuat dan mengikuti kebugaran yang sebenarnya sehingga kebugaran yang sebenarnya selalu mengikuti. Tidak ada kasus khusus dalam pengajaran, terutama dalam iklim sekolah. kebugaran yang sebenarnya di lingkungan sekolah harus didorong untuk mencapai tingkat pengajaran dan pembelajaran yang ideal, karena pencipta menerima bahwa siswa yang memiliki kebugaran yang baik juga akan menyelesaikan tugas belajar mereka dengan baik. Selain itu, dengan kondisi kebugaran yang baik, siswa akan benar-benar ingin mengembangkan keterampilan nyata yang memungkinkan siswa untuk tertarik pada berbagai tugas proaktif, dan memiliki opsi untuk mengembangkan kebugaran yang sebenarnya untuk hidup efektif dalam keadaan mereka saat ini. kebugaran menurut arifin dan haris, (2018) adalah "tingkat kesejahteraan unik individu yang merupakan kapasitas aktual yang menjadi alasan efektif pelaksanaan tugas yang harus diselesaikan".

Mengenai hal tersebut di atas, qohhar, (2017) menjelaskan bahwa "seorang siswa yang membuat ulah tubuh akan benar-benar ingin menyelesaikan tugas-tugas proaktif setiap hari tanpa kelelahan kritis. Kemudian lagi, tingkat kebugaran yang rendah akan menjadi penghalang dalam 
menyelesaikan latihan. kebugaran yang sebenarnya diperlukan oleh orang-orang, karena faktorfaktor ini sangat mendukung efek samping dari latihan yang dilakukan kebugaran yang diidentifikasikan oleh siswa adalah perspektif penting yang harus dipertahankan untuk menjaga kebugaran mereka, siswa harus memiliki pilihan untuk mengarahkan gaya hidup mereka dengan berolahraga secara konsisten, siswa akan memiliki tingkat kebugaran yang baik sehingga mereka dapat mengembangkan latihan mereka di sekolah (prakoso, 2015) hal ini sesuai dengan penilaian hasibuan (2010) , yang menjelaskan bahwa upaya kebugaran yang sebenarnya adalah upaya kesejahteraan yang menggunakan kerja aktif untuk lebih mengembangkan kesejahteraan. kebugaran akan lebih mengembangkan kesejahteraan atau dengan demikian, kesehatan yang sebenarnya diidentikkan dengan kesejahteraan, salah satunya adalah kelebihan berat badan.

Kegemukan merupakan penyebab berbagai penyakit tidak menular seperti diabetes, hipertensi dan infeksi kardiovaskular, yang sampai saat ini masih menjadi masalah medis, khususnya di indonesia dan diperkirakan akan terus meningkat pada tahun 2020 (nugroho, 2020). Selanjutnya, pengajaran diharapkan dapat mendorong siswa untuk melakukan pekerjaan aktif untuk menghindari berat badan. Berat badan adalah salah satu kondisi medis utama di negara-negara berkembang dan non-industri.

Dalam penelitian ini, digunakan dua sekolah yang dibiayai pemerintah yaitu sekolah negeri yang menggambarkan sekolah dari smpn 1 purwakarta kota dan sekolah negeri yang menggambarkan sekolah dari smpn 2 cibatu desa. Smpn 1 purwakarta adalah sekolah negeri yang menggambarkan sekolah dari sebuah kota yang terletak di kecamatan purwakarta, kabupaten purwakarta, provinsi jawa barat. Area penting sekolah berada di kota metropolitan dimana akses ke sekolah sangat sederhana, transportasi umum dapat mencapai ke depan pintu masuk sekolah, sehingga siswa tidak perlu berjalan kaki. Smpn 2 cibatu adalah sekolah negeri yang menggambarkan sekolah dari sebuah desa yang terletak di kecamatan cibatu, kabupaten purwakarta, provinsi jawa barat. Untuk masuk ke smpn 2 cibatu sangat merepotkan mengingat tidak adanya transportasi terbuka yang bisa sampai ke depan sekolah. Banyak siswa pergi ke kelas dengan berjalan kaki. Manfaat jalan kaki adalah dapat meningkatkan kekuatan otot-otot kaki yang akan mempengaruhi bagian-bagian kebugaran yang sebenarnya dan meningkatkan daya tahan siswa. Karena mereka terbiasa berjalan-jalan, siswa smpn 2 cibatu memiliki tingkat pekerjaan yang baik sehingga mempengaruhi tingkat kebugaran mereka.

Berdasarkan uraian di atas, penelitian ini bertujuan untuk memberdayakan mahasiswa yang berkonsentrasi di perkotaan dan pedesaan untuk mengetahui tingkat kebugaran yang sebenarnya dan meningkatkan semangat kerja agar terhindar dari kegemukan. Selanjutnya, analis tertarik untuk memimpin eksplorasi dengan mengambil judul "profil tingkat kebugaran jasmani antara siswa yang bersekolah di kota (smp 1 purwakarta) dan di desa (smp 2 cibatu) di kabupaten purwakarta".

\section{METODE}

Pemeriksaan ini merupakan penelitian kuantitatif dengan menggunakan teknik tinjauan atau survey. Seperti yang dikemukakan oleh Yuliana dan Sugiharto, (2019) Penelitian Deskriptif adalah penelitian yang secara eksklusif berarti menemukan keadaan suatu barang atau peristiwa tanpa bertujuan untuk mencapai kesimpulan umum. Teknik yang digunakan dalam pengujian ini adalah Metode Survey, sedangkan pengumpulan informasi menggunakan Tes dan Pengukuran. Seperti yang ditunjukkan oleh Oktafiani, (2014) Metode Survei adalah pemeriksaan yang diarahkan untuk memperoleh kenyataan dari efek samping yang ada dan mencari kekurangan yang dapat diverifikasi. Jenis tinjauan yang digunakan adalah Cross Sectional Survey, Cross Sectional Survey adalah penelitian studi dimana latihan pengumpulan informasi yang didapat dari suatu contoh dilakukan dalam satu saat dan tidak memerlukan waktu yang cukup lama, Pemilahan data dapat diperoleh dari melihat contoh-contoh atau setiap orang dalam populasi. 
Populasi dalam ujian ini adalah sekolah menengah pertama yang menggambarkan sekolah dari kota dan sekolah menengah pertama yang menggambarkan sekolah dari desa di Kabupaten Purwakarta yang berjumlah 80 sekolah sehingga prosedur pengujian menggunakan pemeriksaan purposive.

Dalam pengujian ini, contoh diambil dengan menggunakan Metode Purposive Sample. Seperti yang dikemukakan oleh Krisdiana et al., (2014) menjelaskan bahwa purposive sample dilakukan dengan mengambil subyek yang tidak didasarkan pada lapisan, arbitrer atau teritorial, namun berdasarkan tujuan tertentu. Prasyarat yang harus dipenuhi dalam pengujian ini adalah: (a) siswa kelas VIII. (b) Bersedia mengikuti TKJI bagi remaja berusia 13-15 tahun. (c) Area sekolah berada di pusat kota dan kendaraan umum dapat mencapai depan pintu sekolah. (d) Area sekolah berada di wilayah desa dan tidak ada transportasi terbuka yang dapat mencapai ke depan pintu masuk sekolah.

Dari syarat-syarat yang dikemukakan di atas, contoh dalam ujian ini adalah siswa kelas VIII SMPN 2 Cibatu 60 siswa dan siswa kelas VIII SMPN 1 Purwakarta 60 siswa yang akan mengikuti TKJI untuk usia dewasa 13-15 tahun.

Tes yang digunakan untuk mengukur Tingkat Kesegaran Jasmani siswa SMPN 2 Cibatu yang beralamatkan desa dan siswa SMPN 1 Purwakarta yang beralamat kota adalah TKJI untuk remaja usia 13-15 tahun RIDWAN, n.d. (2015). Nilai Keabsahan dan Keandalan Instrumen yang digunakan memuat Nilai Keabsahan TKJI untuk usia 13-15 tahun, remaja putra: 0.950 (Doolittle), remaja putri: 0.923 (Aitken). terlebih lagi, skor kualitas yang tak tergoyahkan untuk pria muda berusia 13-15 tahun: 0.960 (Doolittle), wanita muda: 0.804 (Aitken).

Penelitian ini merupakan penelitian kuantitatif yang bertujuan untuk memberikan gambaran yang nyata sesuai dengan apa yang ada di lapangan tentang tingkat kebugaran yang sebenarnya antara siswa di SMPN 1 Purwakarta yang menggambarkan sekolah dari kota dan siswa di SMPN 2 Cibatu yang menggambarkan sekolah dari desa. Penyelidikan informasi yang digunakan dalam eksplorasi ini adalah investigasi dan persentase.

Investigasi Kelas Tingkat Kebugaran Jasmani Siswa SMPN 1 Purwakarta yang menggambarkan sekolah dari Kota dan Siswa SMPN 2 Cibatu yang menggambarkan sekolah dari desa, strategi ujian informasi ini diurutkan menjadi 5 klasifikasi termasuk umumnya sangat baik, baik, sedang, kurang dan sangat kurang. Dalam penelitian ini, strategi penelusuran informasi yang digunakan adalah melibatkan prosedur dengan tingkat klasifikasi silang dengan norma standar kebugaran dari TKJI untuk mengukur tingkat kebugaran siswa yang sebenarnya. Informasi yang diperoleh dari setiap hal tes masih informasi kasar, kemudian hasil tersebuh diubah menjadi nilainilai dengan konseling tabel nilai tes kebugaran yang sebenarnya jatuh tempo 13-15 tahun dan disesuaikan dengan jenis kelamin siswa. Tabel kualitas TKJI dewasa 13-15 tahun adalah:

Tabel 1. Nilai TKJI

(Putra Usia 13-15)

\begin{tabular}{cccccc}
\hline Lari 50 M & $\begin{array}{c}\text { Gantung } \\
\text { Angkat } \\
\text { Badan }\end{array}$ & Sit-Up & $\begin{array}{c}\text { Vertical } \\
\text { Jump }\end{array}$ & Lari 1000 M & Nilai \\
\hline $\mathrm{S}, \mathrm{d}-6.7 \mathrm{~d}$ & $16-$ keatas & $38-$ keatas & $66-$ keatas & s.d $-3.04 \mathrm{~m}$ & 5 \\
$6.8 \mathrm{~d}-7.6 \mathrm{~d}$ & $11-15$ & $28-37$ & $53-65$ & $3.05 \mathrm{~m}-3.53 \mathrm{~m}$ & 4 \\
$7.7 \mathrm{~d}-8.7 \mathrm{~d}$ & $6-10$ & $19-27$ & $42-52$ & $3.54 \mathrm{~m}-4.46 \mathrm{~m}$ & 3 \\
$8.8 \mathrm{~d}-10.3 \mathrm{~d}$ & $2-5$ & $8-18$ & $31-41$ & $4.47 \mathrm{~m}-6.05 \mathrm{~m}$ & 2 \\
$10.4 \mathrm{~d}-\mathrm{dst}$ & $0-1$ & $0-7$ & $30-\mathrm{dst}$ & $6.05 \mathrm{~m}$ dst & 1 \\
\hline
\end{tabular}

Sumber: Depdiknas Pusat Pengembangan Kualitas Jasmani, 2015. 
Tabel 2. Nilai TKJI

(Putri Usia 13-15)

\begin{tabular}{cccccc}
\hline Lari 50 M & $\begin{array}{c}\text { Gantung } \\
\text { Sikuk Tekuk }\end{array}$ & Sit-Up & $\begin{array}{c}\text { Vertical } \\
\text { Jump }\end{array}$ & Lari 800 M & Nilai \\
\hline S,d-7.7 d & $41 \mathrm{~d}-$ keatas & $28-$ keatas & $50-$ keatas & S.d $-3.06 \mathrm{~m}$ & 5. \\
$7.8 \mathrm{~d}-8.7 \mathrm{~d}$ & $22 \mathrm{~d}-40 \mathrm{~d}$ & $19-27$ & $39-49$ & $3.07 \mathrm{~m}-3.55 \mathrm{~m}$ & 4. \\
$8.8 \mathrm{~d}-9.9 \mathrm{~d}$ & $10 \mathrm{~d}-21 \mathrm{~d}$ & $9-18$ & $30-38$ & $3.56 \mathrm{~m}-4.58 \mathrm{~m}$ & 3. \\
$10.0 \mathrm{~d}-11.9 \mathrm{~d}$ & $3 \mathrm{~d}-9 \mathrm{~d}$ & $3-8$ & $21-29$ & $4.49 \mathrm{~m}-6.40 \mathrm{~m}$ & 2. \\
$12.0 \mathrm{~d} d \mathrm{dst}$ & $0 \mathrm{~d}-2 \mathrm{~d}$ & $0-2$ & $20-\mathrm{dst}$ & $6.41 \mathrm{~m} \mathrm{dst}$ & 1. \\
\hline
\end{tabular}

Sumber: Depdiknas Pusat Pengembangan Kualitas Jasmani, 2015.

Setelah mengetahui nilai dari masing-masing ragam uji tersebut, maka dari masing-masing nilai ujian tersebut dijumlahkan dan hasil penjumlahan dari nilai tersebut digunakan sebagai dasar untuk menentukan kategori siswa yang sebenarnya. tingkat kebugaran dengan masuk ke dalam tabel standar norma TKJI yang berusia 13-15 tahun, maka dengan cara ini kondisi kebugaran siswa yang sebenarnya dapat diketahui. Standar baku TKJI yang berusia 13-15 tahun dapat dilihat pada tabel di bawah ini:

Tabel 3. Norma TKJI

(putra dan putri usia 13-15 tahun)

\begin{tabular}{ccc}
\hline No & Nilai & Klasifikasi \\
\hline 1. & 22 s.d 25 & Baik Sekali \\
2. & 18 s.d 21 & Baik \\
3. & 14 s.d 17 & Sedang \\
4. & 10 s.d 13 & Kurang \\
5. & 5 s.d 9 & Kurang Sekali \\
\hline
\end{tabular}

Sumber: Depdiknas Pusat Pengembangan Kualitas Jasmani, 2015.

Data yang terkumpul dari menjumlahkan ragam tes kemudian diubah ke dalam tabel kategori TKJI usia 13-15 tahun. Kemudian dianalisis menggunakan investigasi dan persentase dengan rumus:

$$
\text { Presentase }=\left(\frac{\sum \text { kategori }}{\sum \text { total }}\right) \times 100 \%
$$

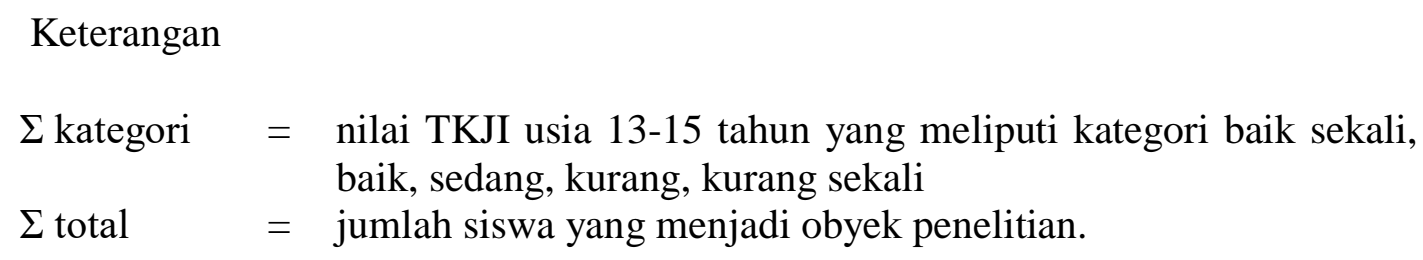

\section{HASIL DAN PEMBAHASAN}

Berdasarkan tujuan pengujian untuk menentukan perbedaan tingkat kebugaran yang sebenarnya antara siswa yang konsentrasi di kota (SMPN 1 Purwakarta) dan di desa (SMPN 2 Cibatu) di Kabupaten Purwakarta. prosedur pemeriksaan menggunakan pemeriksaan bertujuan dengan ketentuan sebagai berikut: (a) Siswa kelas VIII, (b) Bersedia mengikuti TKJI yang berusia 
13-15 tahun, (c) Wilayah sekolah terletak di pusat kota dan angkutan umum dapat mencapai depan pintu masuk sekolah, (d) Area sekolah terletak di daerah pedesaan dan tidak ada transportasi terbuka yang dapat mencapai ke depan pintu sekolah. Dari kebutuhan yang dikemukakan di atas, yang dimaksud dengan contoh dalam ujian ini adalah siswa kelas VIII di SMPN 1 Purwakarta dan siswa kelas VIII di SMPN 2 Cibatu yang akan menempuh TKJI berusia 13-15 tahun.

Tabel 4. Jumlah siswa yang mengikuti TKJI usia 13-15 tahun

\begin{tabular}{cccc}
\hline Sekolah & Jenis Kelamin & Frekuensi & Persentase \\
\hline \multirow{3}{*}{ SMPN 1 Purwakarta } & Putra & 20 Orang & $33 \%$ \\
& Putri & 40 Orang & $67 \%$ \\
& Total & 60 Orang & $100 \%$ \\
\multirow{2}{*}{ SMPN 2 Cibatu } & Putra & 20 Orang & $33 \%$ \\
& Putri & 40 Orang & $67 \%$ \\
& Total & 60 Orang & $100 \%$ \\
\hline
\end{tabular}

\section{Hasil}

1. Tingkat Kebugaran Jasmani SMPN 1 Purwakarta

Gambaran Tingkat Kebugaran Jasmani Siswa di SMPN 1 Purwakarta mendapat nilai terkecil (paling sedikit) 9,00, nilai paling penting (terbesar) 17,00, normal (rata-rata) 12,83, nilai tengah (tengah) 13,00, nilai paling gencar (modus) 13.00, standar deviasi (SD) 1,67. Hasil total dapat ditemukan pada tabel 5 sebagai berikut:

Tabel 5. Data SMPN 1 Purwakarta

\begin{tabular}{cc}
\hline \multicolumn{2}{c}{ Statistik } \\
\hline $\mathrm{N}$ & 60 \\
Rata-rata & 12,83 \\
Nilai tengah & 13,00 \\
Paling gencar & 13,00 \\
Standar deviasi & 1,67 \\
Terkecil & 9,00 \\
Terbesar & 17,00 \\
\hline
\end{tabular}

Adapun poin yang ditampilkan sebagai rekurensi sosialisasi Tingkat Kebugaran Jasmani Siswa di SMPN 1 Purwakarta sebagai berikut:

Tabel 6. Rekurensi Sosialisasi TKJI SMPN 1 Purwakarta

\begin{tabular}{|c|c|c|c|c|}
\hline No & Nilai & Kategori & Frekuensi & Persentase \\
\hline 1 & 22 s.d 25 & Baik Sekali & 0 & 0 \\
\hline 2 & 18 s.d 21 & Baik & 0 & 0 \\
\hline 3 & 14 s.d 17 & Sedang & 21 & $35 \%$ \\
\hline 4 & 10 s.d 13 & Kurang & 37 & $62 \%$ \\
\hline 5 & 5 s.d 9 & Kurang Sekali & 2 & $3 \%$ \\
\hline \multicolumn{3}{|c|}{ Jumlah } & 60 & $100 \%$ \\
\hline
\end{tabular}

Dilihat dari persebaran rekurensi pada tabel di atas, maka jika digambarkan secara garis besar, selanjutnya adalah diagram batang Tingkat Kebugaran Jasmani Siswa SMPN 1 Purwakarta. 


\section{Gambar 1. Diagram Batang TKJI Siswa SMPN 1 Purwakarta}

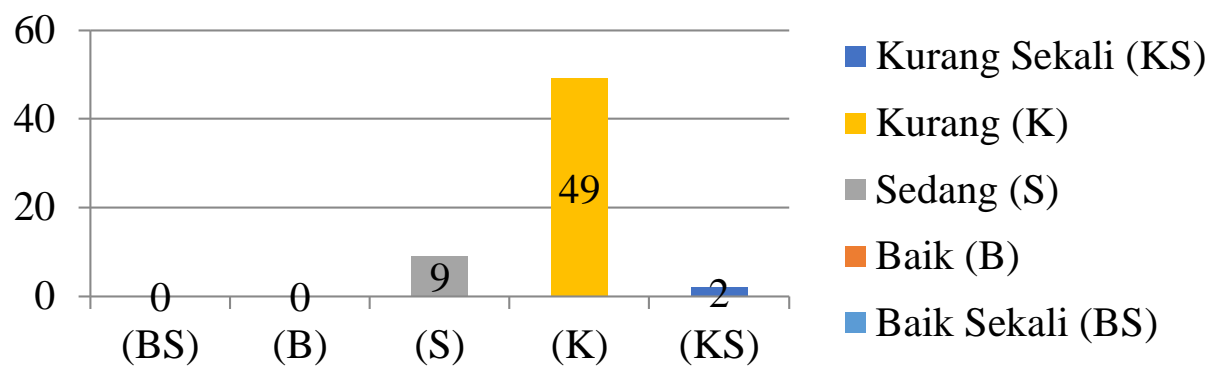

Dilihat dari tabel 6 dan gambar 1 di atas menunjukkan bahwa Tingkat Kebugaran Jasmani Siswa SMPN 1 Purwakarta berada pada kelas "sangat kurang" sebesar 3\% (2 siswa), "kurang" sebesar 62\% (37 siswa), " sedang" sebesar 35\% (21 siswa), "baik" sebesar 0\%, dan "baik sekali" sebesar 0\%. Jika dilihat dari nilai normal 12,83, Tingkat Kesegaran Jasmani Siswa SMPN 1 Purwakarta termasuk dalam klasifikasi "kurang".

2. Tingkat Kebugaran Jasmani SMPN 2 Cibatu

Gambaran Tingkat Kebugaran Jasmani Siswa di SMPN 2 Cibatu mendapat nilai terkecil (paling sedikit) 10,00, nilai paling penting (terbesar) 22,00, normal (rata-rata) 15,40, nilai tengah (tengah) 15,00, nilai paling gencar (modus) 14.00, standar deviasi (SD) 2,18. Hasil total dapat ditemukan pada tabel 7 sebagai berikut:

Tabel 7. Data TKJI SMPN 2 Cibatu

\begin{tabular}{cc}
\hline \multicolumn{2}{c}{ Statistik } \\
\hline $\mathrm{N}$ & 60 \\
Rata-rata & 15,40 \\
Nilai tengah & 15,00 \\
Paling gencar & 14,00 \\
Standar deviasi & 2,18 \\
Terkecil & 10,00 \\
Terbesar & 22,00 \\
\hline
\end{tabular}

Adapun poin yang ditampilkan sebagai rekurensi sosialisasi Tingkat Kebugaran Jasmani Siswa di SMPN 2 Cibatu sebagai berikut:

Tabel 8. Rekurensi Sosialisasi TKJI SMPN 1 Purwakarta

\begin{tabular}{|c|c|c|c|c|}
\hline No & Nilai & Kategori & Frekuensi & Persentase \\
\hline 1 & 22 s.d 25 & Baik Sekali & 1 & $1 \%$ \\
\hline 2 & 18 s.d 21 & Baik & 9 & $15 \%$ \\
\hline 3 & 14 s.d 17 & Sedang & 40 & $67 \%$ \\
\hline 4 & 10 s.d 13 & Kurang & 10 & $17 \%$ \\
\hline 5 & 5 s.d 9 & Kurang Sekali & 0 & 0 \\
\hline \multicolumn{3}{|c|}{ Jumlah } & 60 & $100 \%$ \\
\hline
\end{tabular}


Dilihat dari persebaran rekurensi pada tabel di atas, maka jika digambarkan secara garis besar, selanjutnya adalah diagram batang Tingkat Kebugaran Jasmani Siswa SMPN 2 Cibatu.

\section{Gambar 2. Diagram Batang TKJI Siswa SMPN 2 Cibatu}

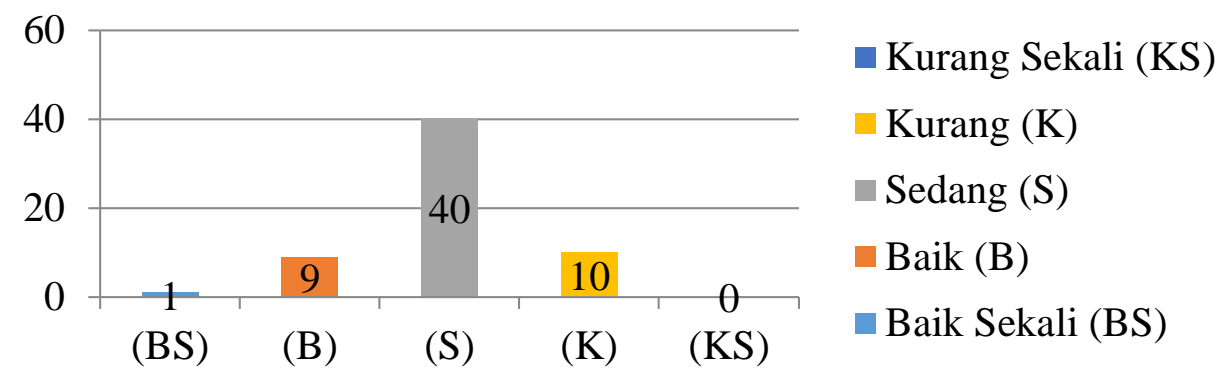

Dilihat dari tabel 7 dan gambar 2 di atas menunjukkan bahwa Tingkat Kebugaran Jasmani Siswa SMPN 1 Purwakarta berada pada kelas "kurang sekali" sebesar 0\%, "kurang” sebesar 17\% (10 siswa), " sedang" sebesar 67\% (40 siswa), "baik" sebesar 15\% (9 siswa), dan "baik sekali" sebesar 1\% (1 siswa). Jika dilihat dari nilai normal 15,40, Tingkat Kebugaran Jasmani Siswa SMPN 2 Cibatu termasuk dalam klasifikasi "sedang".

\section{Pembahasan}

\section{Tingkat Kebugaran Jasmani SMP Negeri 1 Purwakarta}

SMPN 1 Purwakarta dikenal sebagai sekolah dalam kota karena memenuhi ukuran ruang untuk dikenal sebagai kota, SMPN 1 Purwakarta terletak di pusat kota berdampingan dengan alunalun kota, bidang usaha adat, Kantor Bupati, Markas Besar Angkatan Darat ( Kodim), Kantor DPR, dan Kantor Pos. Selain itu, SMPN 1 Purwakarta dikenal sebagai sekolah kota karena wali murid SMPN 1 Purwakarta memiliki kedudukan yang berbeda-beda, sebagian besar walinya bekerja di bidang non pedesaan seperti instruktur, polisi, pendekar, ahli, dan yang lain.

Siswa yang konsentrasi di kota (SMPN 1 Purwakarta) Menurut Abdurrahim dan Hariadi, (2018) dijelaskan bahwa hal ini dikarenakan siswa yang berkonsentrasi di kota biasanya lebih mementingkan masalah akademis daripada bermain di luar rumah. Daripada siswa yang bersekolah di desa, mereka lebih sering melakukan tugas-tugas proaktif seperti bermain, membantu orang tua mereka di ladang, dll.

Berdasarkan hasil penelitian diketahui bahwa Tingkat Kebugaran Jasmani Siswa SMPN 1 Purwakarta berada pada kelas "sangat kurang" sebesar 3\% (2 siswa), "kurang" sebesar 62\% (37 siswa), "sedang" sebesar 35\% (21 siswa), "baik" sebesar 0\%, dan "umumnya sangat baik" sebesar 0\%. Dilihat dari nilai normal sebesar 12,83 maka Tingkat Kesegaran Jasmani Siswa SMPN 1 Purwakarta berada pada kelas "kurang".

2. Tingkat Kebugaran Jasmani SMPN 2 Cibatu

SMPN 2 Cibatu bisa dibilang sekolah yang terletak di desa karena SMPN 2 Cibatu jauh dari pusat kota, jalan depan menuju SMPN 2 Cibatu masih berupa jalan aspal hitam yang rusak. Selain itu, SMPN 2 Cibatu dikenal sebagai sekolah yang terletak di desa dengan alasan tidak adanya sarana transportasi yang sampai di depan pintu masuk sekolah, satu-satunya angkutan umum yang 
dapat diakses untuk masuk ke SMPN 2 Cibatu adalah ojek. Masih ada berton-ton lahan kosong misalnya sawah dan kebun yang melingkupi SMPN 2 Cibatu, ukuran lahan di ruang SMPN 2 Cibatu masih jauh lebih luas dari ruang penduduk. Sebagian besar wali murid SMP Negeri 2 Cibatu berfungsi sebagai peternak, petani dan beberapa wali murid bekerja di instansi pemerintah.

Siswa yang konsentrasi di desa (SMPN 2 Cibatu) Menurut Nugraha, (2015) menyatakan bahwa hal ini dipengaruhi oleh beberapa faktor, misalnya didikan orang tua yang mempengaruhi pekerjaan dan gaji wali, wali yang bekerja di pertanian selalu menyuruh anak-anak mereka untuk ikut keladang, Selain itu, kecenderungan siswa juga mempengaruhi, misalnya pola makan siswa, pola istirahat siswa, dan desain transportasi siswa saat pergi dan pulang sekolah. siswa yang berjalan kaki ke sekolah memiliki kebugaran yang berbeda dari siswa yang menggunakan kendaraan. Sesuai Taufik, (2015) menjelaskan bahwa jalan kaki memberikan banyak manfaat bagi tubuh, seperti memperkuat otot, memperkuat tulang, dan tentu saja bekerja pada kebugaran dan keadaan yang sebenarnya.

Berdasarkan hasil pemeriksaan dinyatakan bahwa Tingkat Kesegaran Jasmani siswa SMPN 2 Cibatu berada pada klasifikasi "sangat buruk" sebesar 0\%, "kurang" sebesar 17\% (10 siswa), "sedang" sebesar 67\% (40 siswa). siswa), "sangat baik" sebesar 15\% (9 siswa), dan "umumnya sangat baik" sebesar 1\% (1 siswa). Jika dilihat dari nilai normal 15,40 maka Tingkat Kebugaran Jasmani Siswa SMPN 2 Cibatu termasuk dalam kategori “sedang”.

\section{KESIMPULAN DAN SARAN}

Berdasarkan hasil pemeriksaan dan percakapan, maka dapat diduga bahwa: (1) Terdapat Kategori Tingkat Kebugaran Jasmani kurang pada Siswa yang ada di Kota (SMP 1 Purwakarta). (2) Terdapat Kategori Tingkat Kebugaran Jasmani Kategori Sedang Dalam Siswayang ada Di Desa (SMPN 2 Cibatu).

Berdasarkan hasil akhir dan hasil penelitian yang ada, maka pada saat itu spesialis memberikan ide sebagai berikut: (1) Bagi analis tambahan untuk mempertimbangkan dan mengerjakan hambatan pemeriksaan ini untuk meningkatkan hasil penelitian. (2) Untuk Siswa memiliki pilihan untuk menjaga kebugaran mereka yang sebenarnya, melalui tugas-tugas proaktif baik di sekolah maupun di rumah. (3) Bagi para pendidik olahraga, penjelajahan ini dapat digunakan sebagai semacam perspektif dalam menunjukkan pembelajaran yang sebenarnya, olahraga dan kebugaran untuk kelas 8 , dan selanjutnya membimbing siswa untuk secara konsisten menjaga kebugarab mereka melalui flatihan yang disesuaikan.

\section{DAFTAR PUSTAKA}

Abdurrahim, F., \& Hariadi, I. (2018). Tingkat Kebugaran Jasmani Siswa Sdntulungrejo 03 Daerah Dataran Tinggi Kecamatan Bumiaji Kota Batu Tahun Pelajaran 2018/2019. Indonesia Performance Journal, 2(2), 68-73.

Anshor, M. (2016). Upaya Meningkatkan Hasil Belajar Backhand Short Service Dalam Permainan Bulutangkis Melalui Metode Resiprokal Pada Siswa Kelas Viii Mts Sabilal Akhyar Ta 2015/2016. Unimed.

Arifin, L. T., \& Haris, I. N. (2018). Pengaruh Penerapan Permainan Tradisional Terhadap Kebugaran Jasmani Siswa Kelas Viii Smpn 1 Ciasem Kabupaten Subang (Studi Eksperimen 
Pada Siswa Kelas Viii Smpn 1 Ciasem). Biormatika: Jurnal Ilmiah Fakultas Keguruan Dan Ilmu Pendidikan, 4(01).

Hasibuan, R. (2010). Terapi Sederhana Menekan Gejala Penyakit Degeneratif. Jurnal Ilmu Keolahragaan, 8(02), 78-93.

Krisdiana, I., Apriandi, D., \& Setyansah, R. K. (2014). Analisis Kesulitan Yang Dihadapi Oleh Guru Dan Peserta Didik Sekolah Menengah Pertama Dalam Implementasi Kurikulum 2013 Pada Mata Pelajaran Matematika (Studi Kasus Eks-Karesidenan Madiun). Jipm (Jurnal Ilmiah Pendidikan Matematika), 3(1).

Nugraha, A. W. (2015). Perbandingan Tingkat Kebugaran Jasmani Siswa Laki-Laki Kelas Vii Di Kota Dan Di Desa (Studi Kasus Pada Tingkat Aktivitas Fisik Siswa Dan Partisipasi Kegiatan Olahraga Di Kabupaten Bojonegoro). Jurnal Kesehatan Olahraga, 3(2).

Nugroho, P. S. (2020). Jenis Kelamin Dan Umur Berisiko Terhadap Obesitas Pada Remaja Di Indonesia. An-Nadaa: Jurnal Kesehatan Masyarakat, 7(2), 110-114.

Oktafiani, F. (2014). Pengaruh Motivasi Belajar Dan Kebiasaan Belajar Siswa Terhadap Hasil Belajar Pada Mata Pelajaran Ekonomi: Survey Pada Peserta Didik Kelas X Iis Di Sma Negeri 16 Bandung. Universitas Pendidikan Indonesia.

Prakoso, D. P. (2015). Pengukuran Tingkat Kebugaran Jasmani Terhadap Siswa Yang Mengikuti Ekstrakurikuler Bolavoli Di Sma Dr. Soetomo Surabaya. Jurnal Pendidikan Olahraga Dan Kesehatan, 3(1).

Qohhar, W. (2017). Dampak Bersepeda Ke Sekolah Terhadap Kebugaran Jasmani Siswa Di Sma Negeri Se-Kota Serang. Jurnal Kependidikan Jasmani Dan Olahraga, 1(1), 43-49.

Ridwan, R. A. L. I. (N.D.). Meningkatkan Kesegaran Jasmani Melalui Pendekatan Permainan Kecil Siswa Smp Negeri 1 Papar Kediri Tahun 2015.

Siregar, S. (N.D.). Pembelajaran Daring Guru Pendidikan Jasmani Olahraga Dan Kesehatan Selama Pandemi Covid-19 Di Sumatera Utara Tahun 2020. Jurnal Ilmu Keolahragaan, 20(1), 93-101.

Syafitri, R. (2020). Pengaruh Pendidikan Terhadap Kejiwaan Manusia. Pena Kreatif: Jurnal Pendidikan, 9(1), 12-18.

Taufik, R. (2015). Hubungan Antara Jalan Kaki Dengan Vo2 Maksimal Pada Siswi Sma Negeri 1 Ngemplak Boyolali. Universitas Muhammadiyah Surakarta.

Yuliana, A., \& Sugiharto, S. (2019). Survei Tes Tingkat Kebugaran Jasmani Atlet Ssb Putra Tugumuda Semarang Usia 14 Tahun. Journal Of Sport Science And Fitness, 5(1), 14-18. 